\title{
Cost Efficiency and Total Factor Productivity: An Empirical Analysis of Pakistan's Insurance Sector
}

\section{Uzma Noreen $^{*}$ and Shabbir Ahmad**}

\begin{abstract}
This study uses data envelopment analysis and the Malmquist index to examine the impact of financial sector reforms on the efficiency and productivity of Pakistan's insurance sector over the period 2000-09. Our results indicate that the sector is cost-inefficient, with an average score of 58 percent-an outcome of the inappropriate use of inputs. The Malmquist productivity index performs better, indicating an improvement in total factor productivity of about 3 percent on average. The second-stage Tobit regression analysis shows that large firms are relatively inefficient from an allocative perspective as they are unable to equate the marginal product of inputs with their factor prices. Furthermore, the results demonstrate that private firms are more efficient than public firms in the nonlife insurance sector. The empirical findings suggest that a more competitive environment, diversified products and innovative technology could improve the productivity of insurance firms in Pakistan.
\end{abstract}

Keywords: Data envelopment analysis, efficiency, productivity, Malmquist index.

JEL classification: C14, D22, G22.

\section{Introduction}

The insurance sector plays a diverse role by supporting individuals, entrepreneurs and companies confronting multiple risks in addition to its role as a financial intermediary. A well-organized insurance sector is essential to promote sustainable economic growth and stabilization by fostering capital mobilization as well as efficient investment through financial markets (State Bank of Pakistan, 2005). Despite the importance of the insurance sector in Pakistan's socioeconomic development and its distinct functions relative to other

\footnotetext{
${ }^{*}$ Lecturer, International Institute of Islamic Economics, International Islamic University, Islamabad.

** Postdoctoral research fellow, Australian Institute of Business and Economics, University of Queensland, Australia; Assistant Professor (on leave), International Institute of Islamic Economics, International Islamic University, Islamabad.
} 
financial institutions, it has not received much attention from policymakers. The sector remains underdeveloped and considerably small in terms of premiums, insurance density and penetration. ${ }^{1}$

Insurance penetration in Pakistan is substantially low at US\$ 6.6 with a density of 0.7 percent in 2009 in comparison with peer countries and across the region. For instance, insurance penetration and density in India were US\$ 54.3 and 5.2 percent in 2009, respectively (Swiss Re, 2010). The low density and dissemination of the insurance business in Pakistan may be a result of the country's low income per capita, general lack of awareness of the importance of insurance, the sharp increase in the cost of living, a low savings rate, inflation, and religious and other cultural factors.

Following the financial liberalization of the early 1990s, Pakistan opened its insurance market to domestic and foreign insurers. However, it was not until the early 2000s that the private insurance sector experienced a growth momentum with the development of its business and domestic firms. The insurance industry in Pakistan has become fairly developed in recent years by transforming from a monopolistic to a competitive market. Like other financial institutions, the insurance industry has also undergone deregulation, but the pace of implementation has been sluggish. As a result, it is the component of the financial sector with the highest share of government ownership (State Bank of Pakistan, 2010).

The growth of the insurance industry and its economic importance has attracted research interest in the wake of financial sector reforms. ${ }^{2}$ While a rich and diverse body of literature focuses on insurance efficiency in developed economies, few studies have measured the performance of the insurance sector in developing countries (see, for example, Mansoor \& Radam, 2000; Kao \& Hwang, 2008), particularly in Pakistan. The present study examines the performance of Pakistan's insurance industry to gauge whether financial sector reforms have improved its efficiency and productivity, and to determine which factors are responsible for these.

Specifically, we concentrate on estimating its cost efficiency, decomposition (into technical and allocative efficiency) and total factor

\footnotetext{
${ }^{1}$ Insurance density is defined as the gross premium per capita and insurance penetration as the gross premium as a percentage of GDP.

${ }^{2}$ See, for instance: Meador, Ryan and Schellhorn (1997); Berger and Humphrey (1997); Cummins and $\mathrm{Zi} \mathrm{(1998);} \mathrm{Worthington} \mathrm{and} \mathrm{Hurley} \mathrm{(2002).}$
} 
productivity (TFP). We also correlate various factors that influence the efficiency of the insurance sector, such as ownership structure, various services offered (life and nonlife insurance policies) and profitability indicators. Thus, the study contributes to the literature on insurance sector efficiency in developing countries in general and Pakistan in particular. It also provides insights into avenues for future research.

Section 2 provides an overview of the insurance sector in Pakistan. Section 3 reviews the relevant literature on efficiency. Section 4 discusses the methodology followed. Section 5 describes the selected variables. Section 6 analyzes the empirical results and Section 7 concludes the paper.

\section{An Overview of Pakistan's Insurance Sector}

Pakistan's insurance sector has a long history that goes back to independence, at which time, the sector was heavily dominated by foreign insurance companies. There were 77 foreign companies operating in Pakistan compared to seven domestic companies, most of them stateowned. In 1953, the Government of Pakistan set up the Pakistan Insurance Corporation to encourage local insurers to participate. Subsequently, the National Co-Insurance Scheme was launched with the support of local insurers to compete with foreign insurers by increasing the participation of local firms and helping smaller insurance firms compete with foreign rivals. As a result, the number of local firms grew to 60 while that of foreign insurance firms fell to seven. Until 1972, the insurance sector was run by private companies. However, in 1972, the life insurance sector was nationalized and the State Life Insurance Corporation was established, which took over all the assets and liabilities of the private sector. In 1976, the National Insurance Corporation was established to nationalize the general insurance business.

Like many other developing countries, Pakistan initiated financial sector reforms in the 1990s. As a result of financial deregulation, private domestic and foreign firms were allowed to enter the insurance business, although the pace of new entries remained slow. Although the government stepped in to provide a level playing field for the private sector, state-owned corporations continued to dominate the life insurance market, likely due to their large networks and customer base, expertise and low premium rates. On the other hand, the growth of nonlife insurers in the private sector was constrained by their lack of professional expertise and small capital base compared to state-owned firms (State Bank of Pakistan, 2005). 
The insurance industry underwent significant structural changes after the Securities and Exchange Commission of Pakistan (SECP) introduced a series of reforms to help make the nonbanking financial sector more competitive. The most significant development was the promulgation of the Insurance Ordinance 2000, which laid down a comprehensive regulatory framework for the insurance industry. The purpose of this ordinance was to develop a dynamic, competitive insurance industry by strengthening regulatory and supervisory measures (State Bank of Pakistan, 2005).

With the implementation of the ordinance, both the public and private sectors saw a persistent improvement in their capital base, asset structure $^{3}$ and profitability. The new regulatory requirements also led to the closure of weak, unprofitable private sector insurers, particularly in the nonlife sector. In the last few years, Pakistan's insurance industry has shown signs of healthy growth. ${ }^{4}$ Several other factors have also contributed to this: an overall stable macroeconomic environment, improved per capita income, the growth of private sector credit and the expansion of the trade sector (State Bank of Pakistan, 2008).

Table 1 shows the asset composition of the insurance sector in state-owned, private and foreign companies, both under life and nonlife insurance. Clearly, life insurance dominates the overall industry.

Table 1: Asset structure of the insurance industry, 2001-09

(Shares in percent)

\begin{tabular}{lrrrrrrrrr}
\hline Shares & $\mathbf{2 0 0 1}$ & $\mathbf{2 0 0 2}$ & $\mathbf{2 0 0 3}$ & $\mathbf{2 0 0 4}$ & $\mathbf{2 0 0 5}$ & $\mathbf{2 0 0 6}$ & $\mathbf{2 0 0 7}$ & $\mathbf{2 0 0 8}$ & $\mathbf{2 0 0 9}$ \\
\hline Life & 73.7 & 73.7 & 71.4 & 71.0 & 70.6 & 67.1 & 59.0 & 62.2 & 64.3 \\
State-owned & 71.6 & 71.2 & 67.7 & 66.8 & 65.5 & 61.5 & 52.2 & 56.2 & 56.3 \\
Private & 1.1 & 1.5 & 2.4 & 2.6 & 3.1 & 3.3 & 4.3 & 3.6 & 5.0 \\
Foreign & 0.9 & 1.0 & 1.3 & 1.6 & 2.0 & 2.3 & 0.8 & 2.4 & 3.0 \\
Nonlife & 23.4 & 23.1 & 24.5 & 25.5 & 26.6 & 30.2 & 37.3 & 33.4 & 31.7 \\
State-owned & 9.9 & 9.4 & 9.3 & 8.6 & 8.4 & 7.4 & 6.6 & 6.5 & 6.9 \\
Private & 12.7 & 12.8 & 14.2 & 15.9 & 17.4 & 22.0 & 30.0 & 26.2 & 24.0 \\
Foreign & 0.8 & 0.9 & 1.0 & 0.6 & 0.8 & 0.8 & 0.8 & 0.7 & 0.7 \\
Reinsurance & 2.9 & 3.2 & 4.1 & 3.8 & 2.8 & 2.6 & 3.2 & 3.6 & 3.2 \\
\hline
\end{tabular}

\footnotetext{
${ }^{3}$ Under the Insurance Ordinance, the SECP required general insurers to raise their paid-up capital from PRs 120 million in 2007 to PRs 300 million by 2011. Life insurers were required to increase their paid-up capital from PRs 300 million to PRs 500 million by the end of 2011.

${ }^{4}$ In recent years, there has been a significant increase in gross premiums: about 17 percent in the nonlife sector and 36 percent in the life sector (Insurance Association of Pakistan, 2008).
} 


\begin{tabular}{lrrrrrrrrr}
\hline Shares & $\mathbf{2 0 0 1}$ & $\mathbf{2 0 0 2}$ & $\mathbf{2 0 0 3}$ & $\mathbf{2 0 0 4}$ & $\mathbf{2 0 0 5}$ & $\mathbf{2 0 0 6}$ & $\mathbf{2 0 0 7}$ & $\mathbf{2 0 0 8}$ & $\mathbf{2 0 0 9}$ \\
\hline State-owned & 2.9 & 3.2 & 4.1 & 3.8 & 2.8 & 2.6 & 3.2 & 3.6 & 3.2 \\
Takaful & $\ldots$ & $\ldots$ & $\ldots$ & $\ldots$ & $\ldots$ & 0.3 & 0.5 & 0.7 & 0.8 \\
GDP share & 2.6 & 2.8 & 2.9 & 2.8 & 2.9 & 3.0 & 3.4 & 2.9 & 2.8 \\
Total assets* & 113.4 & 129.8 & 151.4 & 174.6 & 201.7 & 246.1 & 325.1 & 341.4 & 386.8 \\
\hline
\end{tabular}

* Assets in billion rupees.

Source: State Bank of Pakistan, Financial Stability Review for 2007/08 and 2009/10.

The life insurance business is still dominated by publicly owned companies, which constitute about 56 percent of the life insurance business in Pakistan. Nonlife insurance constitutes only 31 percent of the insurance industry, although its share has grown significantly from 23.4 percent in 2001 to 31.3 percent in 2009. Notably, the bulk of the nonlife business is owned by the private sector compared to the life insurance subsector. As the last row of the table shows, there has been substantial growth in the assets of the insurance industry during 2001-09.

Table 2 presents the capital adequacy measures of the nonlife insurance sector, including the ratio of capital to total assets, equity growth rate and the growth rate of total assets. On average, the nonlife insurance sector has performed well on these indicators during 2002-09. The equity of (nonlife) insurance companies has grown at an average rate of 26.3 percent, while asset growth has remained about 25.3 percent per annum.

Table 2: Capital adequacy measures of nonlife insurance sector

\begin{tabular}{lccc}
\hline Year & $\begin{array}{c}\text { Capital/total } \\
\text { assets }\end{array}$ & $\begin{array}{c}\text { Growth rate of } \\
\text { equity }\end{array}$ & $\begin{array}{c}\text { Growth rate of } \\
\text { assets }\end{array}$ \\
\hline 2002 & 17.0 & 18.1 & 18.7 \\
2003 & 15.0 & 15.3 & 13.8 \\
2004 & 15.0 & 19.1 & 45.8 \\
2005 & 12.0 & 27.4 & 22.1 \\
2006 & 11.0 & 59.3 & 34.8 \\
2007 & 7.8 & 72.2 & 67.1 \\
2008 & 10.3 & -9.8 & -5.9 \\
2009 & 10.3 & 8.8 & 7.9 \\
Average & 12.3 & 26.3 & 25.5 \\
\hline
\end{tabular}

Source: State Bank of Pakistan, Financial Stability Review for 2007/08 and 2009/10.

Table 3 presents the same financial indicators for the life insurance sector, which has also shown considerable improvement in terms of 
performance. Equity and assets have grown at remarkable rates in recent years, having increased to 28 percent and 13.5 percent, respectively.

Table 3: Capital adequacy measures of life insurance sector

\begin{tabular}{lccc}
\hline Year & $\begin{array}{c}\text { Capital/total } \\
\text { assets }\end{array}$ & $\begin{array}{c}\text { Growth rate of } \\
\text { equity }\end{array}$ & $\begin{array}{c}\text { Growth rate of } \\
\text { assets }\end{array}$ \\
\hline 2002 & 1.4 & 18.6 & 14.4 \\
2003 & 1.7 & 20.2 & 12.6 \\
2004 & 1.5 & 37.6 & 15.1 \\
2005 & 1.5 & 31.5 & 14.9 \\
2006 & 1.7 & 28.9 & 15.4 \\
2007 & 1.5 & 40.4 & 17.5 \\
2008 & 1.8 & 2.0 & 11.6 \\
2009 & 1.9 & 44.9 & 6.8 \\
Average & 1.6 & 28.0 & 13.5 \\
\hline
\end{tabular}

Source: State Bank of Pakistan, Financial Stability Review for 2007/08 and 2009/10.

Summing up, the insurance sector in Pakistan indicates healthy trends in recent years. The liberalization of the insurance industry has reduced the share of the public sector, particularly in nonlife insurance, which has encouraged the private sector to enter the market and create a more competitive environment.

\section{The Literature on the Efficiency of the Insurance Sector}

Part of what motivates this study is our aim to evaluate the impact of deregulation and financial liberalization on the efficiency and performance of financial institutions. Several studies measure insurance efficiency using parametric and nonparametric approaches, but most concentrate on developed countries, particularly on the US insurance industry (see Amel, Barnes, Panetta \& Salleo, 2004). These studies focus on efficiency, productivity and scale economies in the US insurance industry and try to correlate these with the pre- and post-deregulation period. For instance, Cummins and Weiss (1993), Gardner and Grace (1993), and Yuengert (1993) measure the X-efficiency of either life or property insurance in the US. Cummins, Weiss and Zi (1999) use a frontier analysis to examine efficiency differences across various organizational forms in the US. Cummins, Tennyson and Weiss (1999) apply the data envelopment analysis (DEA) method to study the efficiency performance of mergers and acquisitions. 
Studies focusing on the performance of the Canadian insurance sector include Bernstein (1999), who analyzes TFP growth in Canadian life insurance over the period 1979-89, and McIntosh (1998), who uses data for 1988-91 to assess the scale efficiency of the Canadian insurance industry. Both studies show that the Canadian insurance sector has improved significantly in terms of efficiency and productivity.

Rees and Kessner (1999) evaluate the direct effects of the pre-1994 European Union (EU) policy of deregulation on the efficiency of British and German life insurance companies. They find that the latter's level of efficiency (48 percent) remained lower than that of the UK market (57 percent). Moreover, the regulatory reforms of the EU Commission have improved buyers' welfare relative to the highly regulated German market. Noulas, Lazaradis, Hatzigayios and Lyroudi (2001) analyze the impact of the legal framework on the efficiency of nonlife insurance in Greece and report an average score of 64.69 percent. Further, they point out that high operating costs and low productivity are the main problems facing the Greek insurance sector. They suggest mergers and acquisitions in the sector to gain benefits from large-scale operations, thus improving efficiency.

Other studies on Europe focus on productivity measurement using the Malmquist index and stochastic frontier analysis. They show that both efficiency and productivity in these countries altered significantly due to deregulation - see Cummins, Turchetti and Weiss (1996) for Italy; Cummins and Rubio-Misas (2006) for Spain; Fenn et al. (2008) for Europe; Bikker and van Leuvensteijn (2008) for the Netherlands.

Although most of the literature centers on the performance of either the US or other developed countries, from 2000 onward many studies have investigated the efficiency and productivity of the insurance sector in Asia. Fukuyama (1997) looks at changes in the production efficiency and productivity of the life insurance sector in Japan, focusing on ownership structures under different economic circumstances. Karim and Jhantasana (2005) apply stochastic frontier analysis to evaluate cost efficiency and its relationship with profitability in Thailand's life insurance industry. The study highlights that firm size is positively correlated with mean efficiency, implying that larger firms adopt best practices. As discussed above, many studies have focused on insurance sector efficiency and productivity in developed as well as developing countries. While all the key studies note that deregulation has improved the efficiency and productivity of the insurance sector worldwide, there is significant variation in efficiency scores across countries. 
The literature concludes that the efficiency of the US insurance sector is primarily a result of scale operations, and the mergers and acquisitions that occurred after liberalization and deregulation. Similarly, the European insurance sector has also improved significantly in terms of efficiency and productivity - partly a result of the consolidation of different companies as well as the diversification and competitive environment generated by recent financial liberalization. Studies on Asian economies share the same premise in terms of efficiency and productivity measures, but their results vary significantly across countries - see Mansoor and Radam (2000); Karim and Jhantasana (2005); Hao and Chou (2005); Jeng and Lai (2005).

Numerous studies have examined Pakistan's banking efficiency to compare and evaluate the sector's performance before and after deregulation - see di Patti and Hardy (2005); Burki and Niazi (2006); Burki and Ahmad (2010). In recent years, the significant growth of the country's insurance sector has warranted further analysis of its efficiency and productivity. This study aims to fill this gap.

\section{Methodological Framework}

The idea of cost efficiency and its decomposition into technical and allocative efficiency was first presented by Farrell (1957), who pointed out that a producer's main concern was how to expand the firm's level of output without having to use more resources. A firm is deemed technically inefficient if it fails to produce the maximum possible output from a given level of input, while allocative inefficiency means that the firm is not using an optimal input mix to produce a certain level of output at given prices (Coelli, 1996). The former arises due to poor management and inferior input quality, while the latter occurs when the firm fails to equate its marginal products with the respective input prices.

A number of frontier techniques are used to measure efficiency, which are further classified as parametric or nonparametric approaches. ${ }^{5}$ Both have specific advantages and disadvantages (see Cummins \& $\mathrm{Zi}$, 1998). ${ }^{6}$ We investigate insurance efficiency within the DEA framework,

\footnotetext{
${ }^{5}$ Parametric approaches include the stochastic frontier approach, the thick frontier approach and the distribution-free approach. Nonparametric approaches include data envelopment analysis and free disposal hull.

${ }^{6}$ The parametric approach entails specifying the functional form of production, cost and profit frontiers, and certain distributional assumptions about the error term. On the other hand, the nonparametric approach does not assume any specific functional form for evaluating efficiency
} 
which is a nonparametric mathematical programming approach to frontier estimation and is based on the work of Farrell (1957) and its extensions. 7 The main advantage of this approach is that it demands less data and does not impose the specification of any functional form. Further, DEA enables one to analyze the efficiency of each firm separately, making it easier to identify efficiency and productivity changes firm by firm (Cummins \& Xie, 2008). The main disadvantage associated with DEA is that it does not separate inefficiency from the error term and considers the entire deviation from the frontier to be inefficiency. However, this drawback can be countered partly by using post-efficiency regression analysis (Worthington \& Hurley, 2002).

The DEA method involves constructing a nonparametric bestpractice frontier or a piecewise linear surface obtained from the observed dataset, which serves as the reference point or benchmark for comparison. The resultant efficiency measure, ranging between 0 (least efficient) and 1 (most efficient), depicts the distance from each unit to the frontier.

\subsection{Measurement of Cost Efficiency}

Cost efficiency measures how close a firm's cost is to what a bestpractice firm's cost would be in producing the same output bundle under the same conditions. The cost (or economic) efficiency of a firm consists of allocative efficiency and technical efficiency. The nonparametric costminimizing approach used in this study allows us to decompose cost efficiency into its different components.

We specify an input price vector to calculate a measure of cost efficiency for each firm by solving this envelopment form of the following linear programming (LP) problem (see Fare, Grosskopf, Norris \& Zhang, 1994):

$$
\begin{aligned}
& \text { Min } w_{i}^{\prime} l_{i}^{*} \text { subject to: } \\
& -q_{i}+Q \lambda \geq 0 \\
& l_{i}^{*}-L \lambda \geq 0
\end{aligned}
$$

and, therefore, does not take into account the error term. Obviously, both approaches have certain advantages and disadvantages.

${ }^{7}$ DEA is used widely in measuring banking efficiency. For a survey of the DEA literature, see Knox Lovell (1993), Ali and Seiford (1993), and Seiford (1996). For a survey of DEA in banking, see Berger and Humphrey (1997). 


$$
\begin{aligned}
& N I^{\prime} \lambda=1 \\
& \lambda \geq 0
\end{aligned}
$$

The symbol $l_{i}^{*}$ in this relationship is the cost-minimizing vector of input quantities (calculated by LP); $w_{i}$ and $q_{i}$ represent input prices and output levels, respectively, for the $i$ th decision-making unit (DMU); $Q$ is the $(m \times n)$ matrix of outputs; $L$ is the $(k \times n)$ matrix of inputs; NI is an $(n \times 1)$ vector; and $\lambda$ is an $(n \times 1)$ vector of constants, where $n$ is the number of DMUs. The cost efficiency of each observation indicates the amount by which the cost of production rises due to technical and allocative inefficiency. In other words, the cost efficiency is the ratio of the minimum cost to the observed cost. The allocative efficiency (AE) is calculated residually by dividing cost efficiency (CE) by technical efficiency (TE), such that $\mathrm{AE}=\mathrm{CE} / \mathrm{TE}$.

To measure technical efficiency, we specify an input-oriented LP problem of the form

$$
\begin{aligned}
& \min _{\gamma, \lambda} \gamma \text { subject to: } \\
& -q_{i}+Q \lambda \geq 0 \\
& \gamma l_{i}-L \lambda \geq 0 \\
& \lambda \geq 0
\end{aligned}
$$

where $\gamma$ is a scalar, $\lambda$ is an $(n \times 1)$ vector of constants, $Q$ is the $(m \times n)$ matrix of outputs and $L$ is the $(k \times n)$ matrix of inputs. For the $i$ th DMU, the vectors $l_{i}$ and $q_{i}$ represent inputs and outputs, respectively. After solving the LP problem given above, the value of $\gamma$ will represent the efficiency score of the $i$ th DMU, where the condition $\gamma \leq 1$ will hold, with a value equal to 1 indicating a technically efficient unit on the frontier. To obtain the value of $\gamma$ for each DMU, the LP problem will be solved $n$ times.

Given the assumption of constant returns to scale, the LP problem (2) does not fully envelop the dataset and thus enlarges the feasible region. Therefore, in the second round, we relax the assumption of constant returns to scale by introducing the convexity constraint $N I^{\prime} \lambda=1$ in (2) and writing it in a modified form, where NI is an $(n \times 1)$ vector while all other symbols are as defined above. A measure of scale efficiency is obtained by substituting the $N I^{\prime} \lambda=1$ restriction with $N I^{\prime} \lambda \leq 1$ in (3): 
$\operatorname{Min} \gamma$

$\gamma, \lambda$ subject to

$-q+Q \lambda \geq 0$

$\gamma l_{i}-L \lambda \geq 0$

$N I^{\prime} \lambda=1$

$\lambda \geq 0$

A common difficulty encountered when measuring technical efficiency using DEA is known as input-slacks and output-slacks, which are sections of the piecewise linear frontier that run parallel to the $\mathrm{x}$-axis or y-axis and may lead to inaccurate measurement of technical, pure technical and scale efficiency in the LP problems specified above. Therefore, it is better to use the multistage methodology suggested by Coelli (1996), which resolves the problem of slacks.

\subsection{Measurement of TFP}

Productivity change is defined as the ratio change in outputs to the change in inputs. We use the Malmquist index to measure changes in efficiency and productivity over time (see, for example, Caves, Christensen \& Diewert, 1982). One can measure the productivity change between periods $t$ and $t+1$ relative to either technology in period $t,\left(M_{0}^{t}\right)$, or relative to technology in period $t+1,\left(M_{0}^{t+1}\right)$, using distance functions:

Following Caves et al. (1982):

$$
M_{0}^{t}=\left[\frac{D_{0}^{t}\left(x^{t+1}, y^{t+1}\right)}{D_{0}^{t}\left(x^{t}, y^{t}\right)}\right] \text { and } M_{0}^{t+1}=\left[\frac{D_{0}^{t+1}\left(x^{t+1}, y^{t+1}\right)}{D_{0}^{t+1}\left(x^{t}, y^{t}\right)}\right]
$$

where the subscript 0 refers to output orientation, $D^{t}\left(D^{t+1}\right)$ represents the distance function at time $t(t+1)$, and $x^{t}\left(x^{t+1}\right)$ and $y^{t}\left(y^{t+1}\right)$ are the input and output vectors at time $t$ and $t+1$. The productivity change measure between two time periods generally changes if the reference technology is different (Cummins \& Weiss, 1996). To avoid an arbitrary choice of reference technology, following Fare et al. (1994), the Malmquist productivity index can be described as the geometric mean of these two indices: 
$M_{0}^{t}\left(x^{t+1}, y^{t+1}, x^{t}, y^{t}\right)=\left[\left\{\frac{D_{0}^{t}\left(x^{t+1}, y^{t+1}\right)}{D_{0}^{t}\left(x^{t}, y^{t}\right)}\right\} \times\left\{\frac{D_{0}^{t+1}\left(x^{t+1}, y^{t+1}\right)}{D_{0}^{t+1}\left(x^{t}, y^{t}\right)}\right\}\right]^{1 / 2}$

When this index exceeds unity, it indicates an increase in productivity between periods $t$ and $t+1$, while an index value of less than unity implies a decline in productivity. A value equal to unity means no change. Fare et al. (1994) decompose this change in productivity into two components (the change due to technical efficiency and the change due to technology) by factoring as follows:

$M_{0}^{t}\left(x^{t+1}, y^{t+1}, x^{t}, y^{t}\right)=\left(\frac{D_{0}^{t}\left(x^{t+1}, y^{t+1}\right)}{D_{0}^{t}\left(x^{t}, y^{t}\right)}\right)\left[\left\{\frac{D_{0}^{t}\left(x^{t+1}, y^{t+1}\right)}{D_{0}^{t+1}\left(x^{t+1}, y^{t+1}\right)}\right\} \times\left\{\frac{D_{0}^{t}\left(x^{t}, y^{t}\right)}{D_{0}^{t+1}\left(x^{t}, y^{t}\right)}\right\}\right]^{1 / 2}$

The first component measures the efficiency change, while the second measures technological change over time. The change in technical efficiency shows the shift in the firm's position relative to the production frontier over time. The value of the efficiency change will be greater than 1 if technical efficiency is higher in period $t+1$ than in period $t$; if efficiency deteriorates between the two periods, then the value will be less than 1.

The second factor, technological change, captures the shift in technology (that is, in the production frontier itself) over time. Thus, values of technological change greater than 1 imply technological progress and values less than 1 indicate technological regress (Cummins \& Weiss, 1996).

\subsection{Second-Stage Regression Analysis: Tobit Model}

In this section, we estimate a Tobit regression model to correlate the sample firms' characteristics with other exogenous factors influencing the efficiency of the insurance industry. ${ }^{8}$ Since our efficiency estimates are continuous and censored at 0 , we estimate Tobit regressions in the second-stage analysis, the standard form of which is:

$$
\begin{aligned}
& y_{i t}^{*}=x_{i t}^{\prime} \beta+\varepsilon_{i t} \\
& y_{i t}=y_{i t}^{*} \text { if } y_{i t}^{*}>0 \\
& y_{i t}=0 \text { if } y_{i t}^{*} \leq 0
\end{aligned}
$$

\footnotetext{
${ }^{8}$ In regression analyses, the DEA-based calculated scores of technical, allocative and cost efficiency are included as dependent variables in three separate regressions.
} 
where $y_{i t}^{*}$ is the latent variable and $y_{i t}$ is the efficiency of the individual insurance company in each year. The panel Tobit regression being estimated is:

$y_{i t}=\alpha_{0}+\sum_{i=1}^{k} \alpha_{i Z_{i t}}+\varepsilon_{i t}$

We use technical, allocative and cost efficiency as the dependent variables obtained in the first-stage analysis; $Z_{i t}$ is a vector of explanatory variables such as the size of the firm, return on assets (ROA), market share and dummies for ownership and business type to explain the efficiency differentials prevailing due to these characteristics.

\section{Dataset and Variables}

Our data on the insurance industry was drawn from the annual reports of insurance companies for the period 2000 through 2009. The sample consists of the 12 largest insurers operating in Pakistan, which accounts for 84 percent of the insurance market overall in terms of premium. 9 Two firms are from the life insurance sector and hold 85 percent of its market share; the remaining ten firms are general insurers that comprise 84 percent of the nonlife insurance sector's market share. A summary of inputs, outputs, input prices and control variables is given in Table 4.

In the literature on insurance efficiency, the choice of input-output variables is subject to intense debate (see Sealey \& Lindley, 1977, for a detailed discussion). Eling and Luhnen (2010b) review 80 studies on insurance efficiency and find that 46 have used claims/benefits as an output while 32 have used the premium as a proxy for output. However, there is no consensus on which is the more appropriate variable as both proxies have their own advantages and disadvantages (see Yuengert, 1993; Diacon, Starkey \& O’Brien, 2002).

In this study, we use two outputs - net premium income ${ }^{10}(\mathrm{Q} 1)$ and invested assets $(\mathrm{Q} 2)$ - in line with the insurance efficiency literature (see Hardwick, 1997; Noulas et al., 2001; Greene \& Segal, 2004; Hao \& Chou, 2005). The net premium (Q1) is a proxy output for the risk

\footnotetext{
${ }^{9}$ In 2009, the total number of insurance companies in Pakistan was 53. We have selected only the top 12 because the remaining firms were too small in terms of size and market share.

${ }^{10}$ The data on the net premium (calculated by excluding reinsurance expenses from the gross earned premium) income is taken from the "statement of premiums" section of insurance firms' annual reports.
} 
pooling/bearing function as policyholders buy risk protection through insurance contracts by paying the premium. The value of the firm's invested assets $11(\mathrm{Q} 2)$ is a proxy measuring the intermediation function ${ }^{12}$ of insurance firms (Cummins \& Xie, 2008; Eling \& Luhnen, 2010a).

Table 4: Summary statistics for inputs, input prices and outputs

\begin{tabular}{lccc}
\hline Variable & Mean & Median & SD \\
\hline Outputs (PRs million) & & & \\
Q1 Net premium & 2,510 & 580 & 4,433 \\
Q2 Invested assets & 11,343 & 943 & 30,585 \\
Inputs & & & \\
L1 Labor (number of employees) & 754 & 272 & 1,121 \\
L2 Total fixed assets (PRs million) & 156 & 63 & 191 \\
L3 Business services (PRs million) & 699 & 87 & 1,746 \\
L4 Equity capital (PRs million) & 2,328 & 722 & 3,860 \\
Input prices & & & \\
P1 Price of labor (PRs) & 342,368 & 316,769 & 175,771 \\
P2 Price of total fixed assets (total fixed assets/total assets) & 0.207 & 0.178 & 0.149 \\
P3 Price of business services (business services/total & 0.060 & 0.040 & 0.066 \\
assets) & & & \\
P4 Price of equity capital (total equity/total assets) & 0.359 & 0.332 & 0.214 \\
Control variables & & & \\
Z1 Total assets (PRs million) & 32,284 & 2,141 & 200,260 \\
Z2 Return on assets (net income/total assets) & 0.0894 & 0.071 & 0.137 \\
Z3 Equity/total assets (ratio) & 0.359 & 0.332 & 0.214 \\
Z4 Market share (in \%, calculated on the basis of premium & 7.338 & 1.837 & 11.458 \\
share of firm in market) & & & \\
Z5 Natural log of total assets & 9.500 & 9.330 & 0.787 \\
Firms/observations & & $12 / 120$ & \\
\hline
\end{tabular}

Source: Authors' calculations.

The choice of input variables is not as controversial as that of outputs in the insurance industry. Three input variables - labor, capital (physical and equity) ${ }^{13}$ and business services (materials) - are used most commonly to measure the efficiency of this sector (Greene \& Segal, 2004; Karim \& Jhantasana, 2005; Jeng, Lai \& McNamara, 2007; Cummins \& Xie,

\footnotetext{
${ }^{11}$ This consists of investment in equities, mutual funds, government securities and fixed income securities, etc. The data on invested assets is taken from the balance sheets of individual firms.

${ }^{12}$ Intermediation activities consist of investing the amount of premiums received until the claim payment date; most of the insurer's net profit is generated from investing in marketable securities.

${ }^{13}$ This is important because insurers need to maintain equity capital to pay out any claims to their policyholders if losses exceed the expected limits.
} 
2008). Eling and Luhnen (2010b) find that 61 out of 95 studies reviewed use at least labor and capital as inputs, and most add a third category (generally business services).

We include four inputs: labor (L1), total fixed assets (L2), business services (L3) (which comprise operating expenses, excluding salaries and depreciation) and financial capital (L4). The insurance industry is laborintensive and expenditure on labor makes up almost a third of the firm's total expenses. ${ }^{14}$ Labor input is measured by the number of employees at each firm. The price of labor (W1) is the sum of total salaries, wages and benefits to employees divided by the total number of employees working at that firm.

We include physical capital (L2) as an input by taking the value of fixed assets (equipment and real estate, etc.). The price (W2) of total fixed assets is calculated by dividing depreciation expenses by total fixed assets. The third input, operating expenses (L3), includes expenditure on real estate, printing and stationery, computers, communication, travel, legal fees, management and advertisement, excluding salaries and depreciation costs. The price of operating expenses (W3) is calculated by dividing business services by total assets. Equity capital (L4) is considered the most important input for insurers. On the basis of the data available, we measure the price of equity capital (W4) by dividing equity capital by total assets.

Insurers, financial analysts and policymakers often need to know which factors determine efficiency differences among firms. Identifying these is important to analyze efficiency and productivity differentials across insurance firms to aid their decision making. We include different variables to examine the relationship between firm size, market share and business environment. For instance, the ROA variable is used to investigate the relationship between profitability and efficiency (Greene \& Segal, 2004).

A common hypothesis in insurance analysis is that larger firms are more efficient than smaller firms based on economies of scale. To capture the effect of firm size on efficiency, we use the log of total assets; to determine the interaction between efficiency changes and firm size, we include the squared term for total assets. Hao and Chou (2005) argue that firms with a larger market share collect more revenue and profits and,

\footnotetext{
${ }^{14}$ Some studies divide labor into two categories: agent labor and home office labor (Fukuyama, 1997; Cummins et al., 1998; Karim \& Jhantasana, 2005). Here, we look at total labor as one category because firms' annual reports do not give separate information on home office and agent labor.
} 
hence, are more efficient than firms with a smaller market share. Market share is thus considered an indicator of the firm's efficiency. The equityto-total-assets ratio gauges the impact of different capital ratios on the firm's efficiency. We also include two dummy variables to capture ownership structure (whether the firm is publicly or privately owned) and business type (life or nonlife insurance), which may also have some effect on efficiency.

We hypothesize that higher profitability (ROA), market share and leverage (equity to total assets) have a positive effect on firm efficiency, but we are not certain about the impact of size (measured by total assets), ownership structure and business type.

\section{Results and Discussion}

This section discusses the results for cost efficiency obtained using DEA $^{15}$ and its decomposition into technical, allocative and cost efficiency. We also measure TFP by decomposing it into technical efficiency change and technological change.

\subsection{Efficiency Scores}

The average efficiency scores of the sample firms for each year are presented in Table 5. These indicate that, on average, the insurance industry is technically efficient. However, its allocative efficiency is somewhat lower, consequently leading to cost inefficiency. We find mixed trends for technical efficiency, although it increases from 96 percent in 2000 to 97 percent in 2009. The average cost efficiency of the sector is only 57 percent over 2000-09, showing that insurance firms could have reduced their expenditure by about 43 percent from the existing level to produce the same output.

\footnotetext{
${ }^{15}$ We use the Data Envelopment Analysis Program developed by Coelli (1996) to measure cost efficiency and the Malmquist index.
} 
Table 5: Average efficiency scores, 2000-09

\begin{tabular}{lccc}
\hline Year & Technical efficiency & Allocative efficiency & Cost efficiency \\
\hline 2000 & 0.964 & 0.668 & 0.643 \\
2001 & 0.972 & 0.701 & 0.681 \\
2002 & 0.952 & 0.690 & 0.655 \\
2003 & 0.924 & 0.668 & 0.610 \\
2004 & 0.935 & 0.690 & 0.647 \\
2005 & 0.956 & 0.631 & 0.612 \\
2006 & 0.932 & 0.549 & 0.525 \\
2007 & 0.985 & 0.489 & 0.480 \\
2008 & 0.958 & 0.461 & 0.447 \\
2009 & 0.972 & 0.484 & 0.477 \\
Mean & 0.955 & 0.603 & 0.577 \\
\hline
\end{tabular}

Source: Authors' calculations.

Notably, the insurance sector's allocative efficiency remains about 40 percent during the period of analysis, which may have contributed significantly to its cost inefficiency. Both allocative and cost efficiency decrease continuously after 2004. The low level of allocative efficiency reveals that firms have not done very well in choosing a cost-minimizing combination of inputs. In other words, they have failed to equalize the marginal rate of technical substitution to the factor price ratio. This implies that their factor inputs are not close substitutes. Keeping in view these results, we can conclude that the insurance industry has generally failed to allocate its resources efficiently.

Figures 1 and 2 illustrate the cost, technical and allocative efficiency of each firm. Of all the firms, State Life remains 100 percent cost-efficient: it has several advantages in being the largest market share holder in terms of branch networks and holds more than 60 percent of the insurance sector's total assets. Similarly, the sector has improved its business, ultimately enhancing its operational efficiency and profitability over time. Having successfully overcome its operational expenditures may have increased the overall efficiency of the industry. 
Figure 1: Average cost efficiency, 2000-09

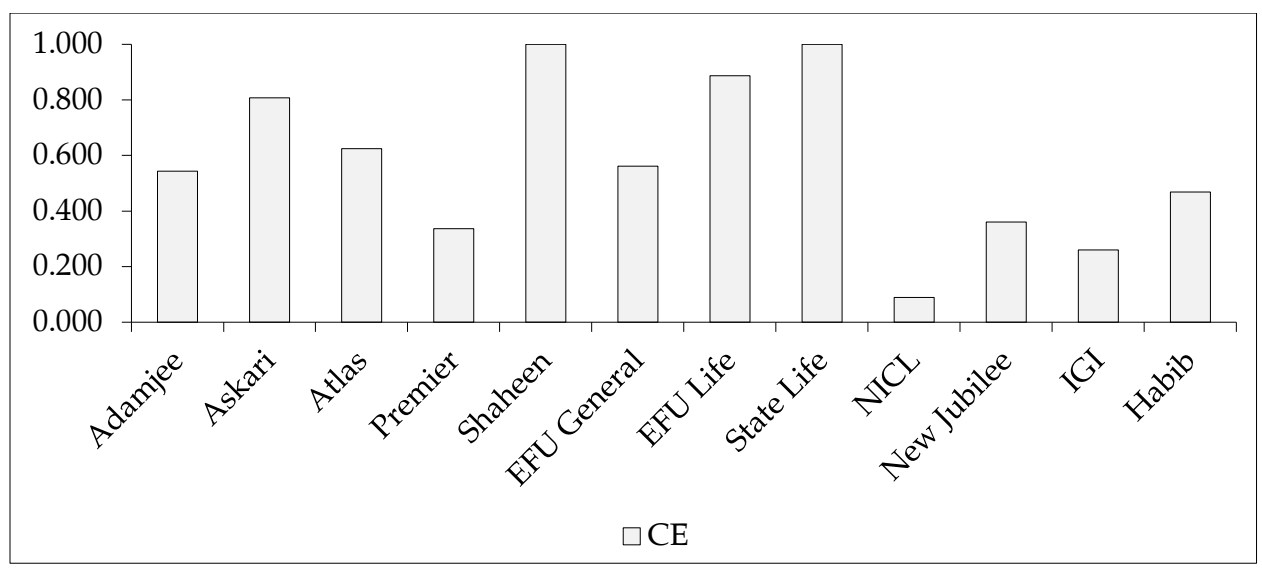

State Life, EFU and NICL are the most technically efficient firms. All three are larger than the others in terms of business volume and outreach, which may have put them at an advantage in optimizing their input resources. Premier remains on the lowest frontier with the smallest efficiency score (0.416). Similarly, Habib and Askari are less efficient than their peer firms. One reason for the low efficiency of these firms may be their limited business diversification, which can hinder firms from using optimal input levels compared to larger firms. To catch up with the efficient firms, these companies need to employ a more efficient input combination.

Figure 2: Average allocative and technical efficiency, 2000-09

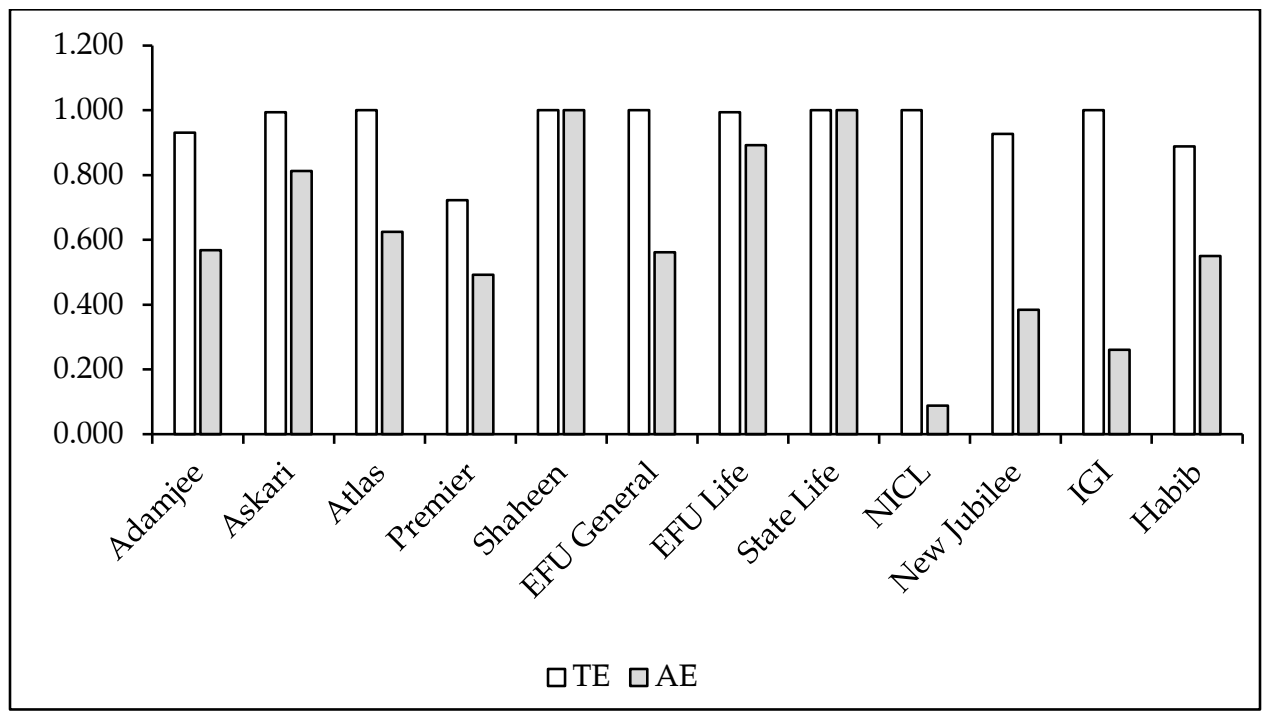


It is important to note that allocative efficiency dominates cost efficiency in our sample. Even firms with the highest technical efficiency show low cost efficiency because they remain less efficient so far as resource allocation is concerned. These results are not unexpected: the insurance sector is highly monopolized and this monopolistic structure and product differentiation may have led firms to be less careful in using their resources efficiently. However, the more competitive environment that has begun to emerge post-deregulation may improve the resource allocation mechanism of the industry in coming years.

\subsection{Malmquist Index Results}

This section presents the results for TFP and its components. There are several methods for computing the Malmquist productivity index (see, for example, Fare et al., 1994). We estimate the output-oriented Malmquist index in this study, which is based on DEA, using a balanced panel of 12 insurance companies to yield the productivity index and its components for Pakistan's insurance sector. Table 6 presents the average results for the Malmquist index and its components, that is, changes in technical efficiency, technology and TFP.

If the value of the Malmquist index and any of its components exceeds unity, this indicates an improvement in performance. A value equal to unity implies no change and a value less than unity reflects a deterioration in performance. The results show that, on average, the insurance sector's TFP (and its components) rose by 3 percent annually. Similarly, there was a significant improvement in technical efficiency, which grew by 2.7 percent on average, consistent with our previous results for cost efficiency obtained on the basis of DEA. However, we find no significant improvement in technological change, which rose on average by a negligible 0.2 percent annually. 
Table 6: Average Malmquist index results, 2001-09

\begin{tabular}{lccc}
\hline Year & EFFCH & TECHCH & TFPCH \\
\hline 2001 & 1.064 & 1.002 & 1.066 \\
2002 & 1.049 & 0.757 & 0.794 \\
2003 & 0.943 & 1.081 & 1.024 \\
2004 & 1.072 & 1.020 & 1.093 \\
2005 & 1.096 & 1.125 & 1.233 \\
2006 & 0.952 & 1.166 & 1.118 \\
2007 & 1.096 & 0.945 & 1.035 \\
2008 & 0.962 & 1.040 & 1.002 \\
2009 & 1.029 & 0.949 & 0.976 \\
Mean & 1.027 & 1.002 & 1.030 \\
\hline
\end{tabular}

Note: EFFCH = efficiency change, TECHCH = technological change, $\mathrm{TFPCH}=$ total factor productivity change.

Source: Authors' calculations.

As the table shows, there was a decline in productivity in 2002, which may have been an outcome of the prudent regulations introduced by the SECP, implemented at the end of 2001. Consequently, the insurance sector also had to comply with these regulations and adjust its operations according to business rules - this may have caused firm productivity to slip. However, soon after 2002, the insurance industry was able to raise its productivity standards in a more competitive environment, which continued to improve in the following years. We also observe that productivity fell in 2009, which may have been a consequence of declining economic growth overall, a high inflation rate, floods, the global financial crisis and Pakistan's internal security situation.

\subsection{Determinants of Efficiency}

In the second stage, we perform a panel Tobit regression analysis to correlate firms' characteristics and exogenous factors with the performance of the sample insurers. ${ }^{16}$ The empirical results are presented in Table 7.

${ }^{16}$ A Tobit specification was used to accommodate the efficiency score left censored at 0 . 


\section{Table 7: Panel Tobit estimates}

\begin{tabular}{|c|c|c|c|c|c|c|}
\hline & \multicolumn{2}{|c|}{ Technical efficiency } & \multicolumn{2}{|c|}{ Allocative efficiency } & \multicolumn{2}{|c|}{ Cost efficiency } \\
\hline & Coeff. & $\begin{array}{l}\text { SE (p- } \\
\text { value) }\end{array}$ & Coeff. & $\begin{array}{l}\text { SE (p- } \\
\text { value) }\end{array}$ & Coeff. & $\begin{array}{l}\text { SE (p- } \\
\text { value) }\end{array}$ \\
\hline Total assets & 0.078 & $\begin{array}{c}0.254 \\
(0.759)\end{array}$ & -1.669 & $\begin{array}{c}0.262 \\
(0.000)\end{array}$ & -1.543 & $\begin{array}{c}0.290 \\
(0.000)\end{array}$ \\
\hline Total assets-sq. & -0.006 & $\begin{array}{c}0.013 \\
(0.655)\end{array}$ & 0.066 & $\begin{array}{c}0.014 \\
(0.000)\end{array}$ & 0.058 & $\begin{array}{c}0.016 \\
(0.000)\end{array}$ \\
\hline $\begin{array}{l}\text { Equity to total } \\
\text { assets }\end{array}$ & 0.002 & $\begin{array}{c}0.073 \\
(0.969)\end{array}$ & -0.923 & $\begin{array}{c}0.075 \\
(0.000)\end{array}$ & -0.881 & $\begin{array}{c}0.084 \\
(0.000)\end{array}$ \\
\hline Market share & 0.002 & $\begin{array}{c}0.002 \\
(0.418)\end{array}$ & 0.014 & $\begin{array}{c}0.002 \\
(0.000)\end{array}$ & 0.016 & $\begin{array}{c}0.003 \\
(0.000)\end{array}$ \\
\hline $\begin{array}{l}\text { Return on } \\
\text { assets }\end{array}$ & 0.039 & $\begin{array}{c}0.083 \\
(0.644)\end{array}$ & 0.166 & $\begin{array}{c}0.086 \\
(0.001)\end{array}$ & 0.182 & $\begin{array}{c}0.095 \\
(0.060)\end{array}$ \\
\hline Ownership & -0.067 & $\begin{array}{c}0.040 \\
(0.103)\end{array}$ & -0.016 & $\begin{array}{c}0.042 \\
(0.693)\end{array}$ & -0.040 & $\begin{array}{c}0.047 \\
(0.389)\end{array}$ \\
\hline Business type & -0.038 & $\begin{array}{c}0.037 \\
(0.312)\end{array}$ & -0.166 & $\begin{array}{c}0.038 \\
(0.144)\end{array}$ & -0.191 & $\begin{array}{c}0.043 \\
(0.000)\end{array}$ \\
\hline 2001 & 0.011 & $\begin{array}{c}0.396 \\
(0.776)\end{array}$ & 0.052 & $\begin{array}{c}0.040 \\
(0.203)\end{array}$ & 0.058 & $\begin{array}{c}0.045 \\
(0.201)\end{array}$ \\
\hline 2002 & -0.006 & $\begin{array}{c}0.040 \\
(0.886)\end{array}$ & 0.048 & $\begin{array}{c}0.041 \\
(0.244)\end{array}$ & 0.044 & $\begin{array}{c}0.046 \\
(0.342)\end{array}$ \\
\hline 2003 & -0.028 & $\begin{array}{c}0.041 \\
(0.496)\end{array}$ & 0.083 & $\begin{array}{c}0.042 \\
(0.052)\end{array}$ & 0.058 & $\begin{array}{c}0.047 \\
(0.218)\end{array}$ \\
\hline 2004 & -0.015 & $\begin{array}{c}0.041 \\
(0.722)\end{array}$ & 0.133 & $\begin{array}{c}0.043 \\
(0.003)\end{array}$ & 0.124 & $\begin{array}{c}0.048 \\
(0.011)\end{array}$ \\
\hline 2005 & 0.010 & $\begin{array}{c}0.042 \\
(0.814)\end{array}$ & 0.158 & $\begin{array}{c}0.044 \\
(0.000)\end{array}$ & 0.174 & $\begin{array}{c}0.049 \\
(0.001)\end{array}$ \\
\hline 2006 & -0.009 & $\begin{array}{c}0.043 \\
(0.832)\end{array}$ & 0.217 & $\begin{array}{c}0.045 \\
(0.000)\end{array}$ & 0.228 & $\begin{array}{c}0.050 \\
(0.000)\end{array}$ \\
\hline 2007 & 0.053 & $\begin{array}{c}0.046 \\
(0.257)\end{array}$ & 0.250 & $\begin{array}{c}0.047 \\
(0.000)\end{array}$ & 0.284 & $\begin{array}{c}0.052 \\
(0.000)\end{array}$ \\
\hline 2008 & 0.033 & $\begin{array}{c}0.050 \\
(0.517)\end{array}$ & 0.216 & $\begin{array}{c}0.051 \\
(0.000)\end{array}$ & 0.245 & $\begin{array}{c}0.058 \\
(0.000)\end{array}$ \\
\hline 2009 & 0.050 & $\begin{array}{c}0.049 \\
(0.318)\end{array}$ & 0.247 & $\begin{array}{c}0.051 \\
(0.000)\end{array}$ & 0.287 & $\begin{array}{c}0.057 \\
(0.000)\end{array}$ \\
\hline Cons. & 0.836 & $\begin{array}{c}1.178 \\
(0.480)\end{array}$ & 10.66 & $\begin{array}{c}1.214 \\
(0.000)\end{array}$ & 10.15 & $\begin{array}{c}1.348 \\
(0.000)\end{array}$ \\
\hline Observations & 120 & & 120 & & 120 & \\
\hline Log likelihood & 110.13 & & 106.53 & & 93.96 & \\
\hline LR chi² (16) & 12.66 & & 275.85 & & 254.01 & \\
\hline
\end{tabular}

Note: We estimate the Tobit year fixed effects and Tobit random effects using a time trend; the results for both are very similar.

Source: Authors' calculations. 
Asset size has an inverse relationship with the performance indicator, implying that larger firms have failed to produce cheaper output vis-à-vis smaller firms. The former's suboptimal use of inputs has increased the cost of producing various insurance services. These results are not unusual if we look at the market structure of the industry, which is highly skewed. This trend continues as the square of the size variable is positive, which emphasizes the promotion of the insurance industry in a more competitive environment.

We also include a leverage (equity to total assets) variable to verify whether firms with more liquidity perform better than those with less liquidity. In contrast to studies such as Cummins and Nini (2002) and Cummins et al. (2007), our results do not support the theory that firms with higher leverage are more efficient than those with less leverage. One of the reasons for this contradiction may be the limited data available. However, what is noticeable is that small insurance companies have a higher capital-to-assets ratio than larger firms, but are less efficient, perhaps due to the limited scale operations discussed earlier.

We introduce a dummy variable for ownership, equal to 1 for private firms and 0 for state-owned firms. The results indicate that stateowned companies lag behind private firms in terms of cost management, particularly in the nonlife sector. However, the dummy variable for the nature of the business shows that life insurance firms are more efficient than nonlife insurance firms. We include ROA to verify the relationship between the firm's profitability and efficiency. The results indicate that more profitable firms tend to be more efficient. Market share also has a significant and positive relationship with the efficiency of an insurance firm.

The cost efficiency of the insurance industry follows a mixed trend over the period of analysis. The technical efficiency results indicate that the insurance sector has been able to produce a given output level using a minimum level of inputs, and expand its operations significantly on the whole. However, allocative efficiency severely affects the overall cost efficiency, possibly given the highly concentrated and regulated nature of the insurance sector in the past.

\section{Conclusion}

This study provides a comprehensive efficiency analysis of Pakistan's insurance sector, which has developed fairly well postliberalization and deregulation. We analyze and decompose the cost 
efficiency of a representative sample of Pakistani insurance firms over the period 2000 to 2009. Our DEA-based results indicate that the sample firms have remained technically efficient. The insurance sector shows 95.5 percent efficiency on average over the period of analysis, but experiences allocative inefficiency, which appears to be the main driver of cost inefficiency overall.

We find mixed trends for cost efficiency in the insurance industry, which may be a sign of the continuing impact of reforms that were initiated to make the sector more competitive and self-reliant. The prevalence of allocative inefficiencies in the insurance sector is likely due to its highly concentrated and regulated nature in the past. It is therefore necessary to remove these distortions as far as possible. The Malmquist productivity index components indicate that technical efficiency has been the main contributor to changes in the sector's productivity. However, we find no evidence that changes in technology itself have improved overall productivity. This suggests a need for innovative and diversified products in the insurance industry in Pakistan.

The main implication of this study is that firms find it difficult to apply cost-effective techniques. Firms should rationalize their expenditure on unprofitable branches and overused labor by adopting modern technologies and rescaling their operations. Incorporating automated processes and empowering clients to transact directly would help in this context. In the changing socioeconomic environment, firms should rethink the traditional products on offer and develop new product lines to cater to the evolving needs of clients and businesses, for instance, crop insurance, livestock insurance and different health insurance products. The insurance business in Pakistan is heavily concentrated: policymakers need to ensure a more competitive environment and market-based options for this sector. Business diversification is likely to have a positive impact on productivity.

While this study estimates the efficiencies of insurance firms in the post-reform period after the Insurance Ordinance 2000 was implemented, future research could extend this to include the performance of firms in the pre-reform period. Furthermore, decomposing productivity into its various components, such as scale and scope economies, could provide key policy insights, given the sector's rapid growth in recent years. 


\section{References}

Ali, A. I., \& Seiford, L. M. (1993). The mathematical programming approach to efficiency analysis. In H. O. Fried, C. A. Knox Lovell \& S. S. Schmidt (Eds.), The measurement of productive efficiency: Techniques and applications (pp. 20-59). New York: Oxford University Press.

Amel, D., Barnes, C., Panetta, F., \& Salleo, C. (2004). Consolidation and efficiency in the financial sector: A review of the international evidence. Journal of Banking and Finance, 28(10), 2493-2519.

Berger, A. N., \& Humphrey, D. B. (1997). Efficiency of financial institutions: international survey and directions for future research. European Journal of Operational Research, 98(2), 175-212.

Bernstein, J. I. (1999). Total factor productivity growth in the Canadian life insurance industry: 1979-1989. Canadian Journal of Economics, 32(2), 500-517.

Bikker, J. A., \& van Leuvensteijn, M. (2008). Competition and efficiency in the Dutch life insurance industry. Applied Economics, 40, 20632084.

Burki, A. A., \& Ahmad, S. (2010). Bank governance changes in Pakistan: Is there a performance effect? Journal of Economics and Business, 62(2), 129-146.

Burki, A. A., \& Niazi, G. S. K. (2006). Impact of financial reforms on efficiency of state-owned, private and foreign banks in Pakistan (CMER Working Paper No. 06-49). Lahore: Lahore University of Management Sciences.

Caves, D., Christensen, L., \& Diewert, W. (1982). The economic theory of index numbers and the measurement of input, output and productivity. Econometrica, 50(6), 1393-1414.

Coelli, T. (1996). A guide to DEAP version 2.1: A data envelopment analysis (computer) program (CEPA Working Paper No. 96/08). Armidale, NSW: University of New England. 
Cummins, J. D., \& Nini, G. (2002). Optimal capital utilization by financial firms: Evidence from the property-liability insurance industry. Journal of Financial Services Research, 21(1), 15-53.

Cummins, J. D., \& Rubio-Misas, M. (2006). Deregulation, consolidation and efficiency: Evidence from the Spanish insurance industry. Journal of Money, Credit and Banking, 38(2), 323-355.

Cummins, J. D., \& Weiss, M. A. (1993). Measuring cost efficiency in the property-liability insurance industry. Journal of Banking and Finance, 17(2-3), 463-481.

Cummins, J. D., \& Weiss, M. A. (1998). Analyzing firm performance in the insurance industry using frontier efficiency methods (Working Paper No. 98-22). Philadelphia, PA: University of Pennsylvania, Wharton Financial Institutions Center.

Cummins, J. D., \& Xie, X. (2008). Mergers and acquisitions in the US property-liability insurance industry: Productivity and efficiency effects. Journal of Banking and Finance, 32(1), 30-55.

Cummins, J. D., \& Zi, H. (1998). Comparison of frontier efficiency methods: An application to the US life insurance industry. Journal of Productivity Analysis, 10(2), 131-152.

Cummins, J. D., Tennyson, S., \& Weiss M. A. (1999). Consolidation and efficiency in the US life insurance industry. Journal of Banking and Finance, 23(2-4), 325-357.

Cummins, J. D., Turchetti, G., \& Weiss, M. A. (1996). Productivity and technical efficiency in the Italian insurance industry (Working Paper No. 96-10). Philadelphia, PA: University of Pennsylvania, Wharton Financial Institutions Center.

Cummins, J. D., Weiss, M. A., \& Zi, H. (1999). Organizational form and efficiency: The coexistence of stock and mutual property-liability insurers. Management Science, 45, 1254-1269.

Diacon, S. R., Starkey, K., \& O'Brien, C. (2002). Size and efficiency in European long-term insurance companies: An international comparison. The Geneva Papers on Risk and Insurance, 27(3), 444-466. 
di Patti, E. B., \& Hardy, D. C. (2005). Financial sector liberalization, bank privatization and efficiency: Evidence from Pakistan. Journal of Banking and Finance, 29(8-9), 2381-2406.

Eling, M., \& Luhnen, M. (2010a). Efficiency in the international insurance industry: A cross-country comparison. Journal of Banking and Finance, 34(7), 1497-1509.

Eling, M., \& Luhnen, M. (2010b). Frontier efficiency methodologies to measure performance in the insurance industry: Overview, systematization and recent developments. The Geneva Papers, 35, 217-265.

Fare, R., Grosskopf, S., Norris, M., \& Zhang, Z. (1994). Productivity growth, technical progress, and efficiency change in industrialized countries. American Economic Review, 84(1), 66-83.

Farrell, M. J. (1957). The measurement of productive efficiency. Journal of the Royal Statistical Society, Series A (General), 120(3), 253-290.

Fenn, P., Vencappa, D., Diacon, S., Klumpes, P., \& O’Brien, C. (2008). Market structure and the efficiency of European insurance companies: A stochastic frontier analysis. Journal of Banking and Finance, 32(1), 86-100.

Fukuyama, H. (1997). Investigating productive efficiency and productivity changes of Japanese life insurance companies. PacificBasin Finance Journal, 5(4), 481-509.

Gardner, L. A., \& Grace, M. F. (1993). X-efficiency in the US life insurance industry. Journal of Banking and Finance, 17(2-3), 497-510.

Greene, W. H., \& Segal, D. (2004). Profitability and efficiency in the US life insurance industry. Journal of Productivity Analysis, 21, 229-247.

Hao, J. C. J., \& Chou, L.-Y. (2005). The estimation of efficiency for life insurance industry: The case in Taiwan. Journal of Asian Economics, 16(5), 847-860.

Hardwick, P. (1997). Measuring cost inefficiency in the UK life insurance industry. Applied Financial Economics, 7(1), 37-44. 
Insurance Association of Pakistan. (2008). Insurance yearbook, 2007-2008 (pp. 20-27). Karachi: Author.

Jeng, V., \& Lai, G. C. (2005). Ownership structure, agency costs, specialization and efficiency: Analysis of keiretsu and independent insurers in the Japanese nonlife insurance industry. Journal of Risk and Insurance, 72(1), 105-158.

Jeng, V., Lai, G. C., \& McNamara, M. J. (2007). Efficiency and demutualization: Evidence from the US life insurance industry in the 1980s and 1990s. Journal of Risk and Insurance, 74(3), 683-711.

Kao, C., \& Hwang, S.-N. (2008). Efficiency decomposition in two-stage data envelopment analysis: An application to nonlife insurance companies in Taiwan. European Journal of Operational Research, 185(1), 418-429.

Karim, M. Z., \& Jhantasana, C. (2005). Cost efficiency and profitability in Thailand's life insurance industry: A stochastic cost frontier approach. International Journal of Applied Econometrics and Quantitative Studies, 2, 19-36.

Knox Lovell, C. A. (1993). Production frontiers and productive efficiency. In H. O. Fried, C. A. Knox Lovell \& S. S. Schmidt (Eds.), The measurement of productive efficiency: Techniques and applications (pp. 3-67). New York: Oxford University Press.

Mansoor, S. A., \& Radam, A. (2000). Productivity and efficiency performance of the Malaysian life insurance industry. Jurnal Ekonomi Malaysia, 34, 93-105.

McIntosh, J. (1998). Scale efficiency in a dynamic model of Canadian insurance companies. Journal of Risk and Insurance, 65(2), 303-317.

Meador, J. W., Ryan, H. E., \& Schellhorn, C. D. (1997). Product focus versus diversification: Estimates of X-efficiency for the US life insurance industry (Working Paper No. 97-16). Philadelphia, PA: University of Pennsylvania, Wharton Financial Institutions Center.

Noulas, A. G., Lazaradis, J., Hatzigayios, T., \& Lyroudi, K. (2001). Nonparametric production frontier approach to the study of 
efficiency of nonlife insurance companies in Greece. Journal of Financial Management and Analysis, 14, 19-26.

Rees, R., \& Kessner, E. (1999). Regulation and efficiency in European insurance markets. Economic Policy, 14(29), 363-397.

Sealey, C. W, \& Lindley, J. T. (1977). Inputs, outputs and a theory of production and cost at depository financial institutions. The Journal of Finance, 32(4), 1251-1266.

Seiford, L. M. (1996). Data envelopment analysis: The evolution of the state of the art (1978-1995). Journal of Productivity Analysis, 7(2-3), 99-137.

State Bank of Pakistan. (2005). Developments in the insurance sector. In Pakistan financial sector assessment 2005 (pp. 105-121). Karachi: Author.

State Bank of Pakistan. (2008). Risk assessment of the insurance sector. In Financial Stability Review 2007-08 (pp. 213-225). Karachi: Author.

State Bank of Pakistan. (2010). Financial stability review 2009-10. Karachi: Author.

Swiss Re. (2010). World insurance in 2009: Premiums dipped, but industry capital improved (Sigma No. 2/2010). Zurich: Author.

Worthington, A. C., \& Hurley, E. V. (2002). Cost efficiency in Australian general insurers: A nonparametric approach. The British Accounting Review, 34(2), 89-108.

Yuengert, A. M. (1993). The measurement of efficiency in life insurance: Estimates of a mixed normal-gamma error model. Journal of Banking and Finance, 17(2-3), 483-496. 